\title{
Detection of Panulirus argus Virus 1 (PaV1) in the Caribbean spiny lobster using fluorescence in situ hybridization (FISH)
}

\author{
Caiwen Li ${ }^{1}$, Jeffrey D. Shields ${ }^{1, *}$, Hamish J. Small ${ }^{1}$, Kimberly S. Reece ${ }^{1}$, \\ Carmony L. Hartwig ${ }^{2}$, Roland A. Cooper ${ }^{2}$, Robert E. Ratzlaff ${ }^{2}$ \\ ${ }^{1}$ Virginia Institute of Marine Science, The College of William and Mary, Gloucester Point, Virginia 23062, USA \\ ${ }^{2}$ Department of Biological Sciences, Old Dominion University, Norfolk, Virginia 23529, USA
}

\begin{abstract}
Panulirus argus Virus 1 (PaV1) is the first virus known to be pathogenic to a wild lobster. It infects the Caribbean spiny lobster $P$. argus from the Florida Keys, and has a predilection for juveniles. The monitoring of the virus in wild populations and study of its behavior in the laboratory require the development of reliable diagnostic tools. A sensitive and specific fluorescence in situ hybridization (FISH) assay was developed for detection of PaV1. The lower detection limit using a 110 bp DNA probe in a dot-blot hybridization for PaV1 DNA was 10 pg of cloned template PaV1 DNA and $10 \mathrm{ng}$ of genomic DNA extracted from the hemolymph of diseased spiny lobster. The fluorescein (FITC)-labeled probe specifically hybridized to PaV1-infected cells in the hepatopancreas, hindgut, gills, heart, foregut, and nerve tissues. FITC staining was observed around the inner periphery of the nuclear membrane, with lighter staining in a more dispersed pattern within the nucleus. The probe did not hybridize with host tissues of uninfected spiny lobsters, nor did it cross-react with 4 other virus samples tested. This assay will facilitate our understanding of the pathogenesis of the viral disease and help in monitoring efforts directed at determining the prevalence of PaV1 in juvenile nurseries for this lobster.
\end{abstract}

KEY WORDS: Crustacea $\cdot$ Viral disease $\cdot$ DNA probe $\cdot$ In situ hybridization $\cdot$ Florida Keys $\cdot$ Diagnostics

\section{INTRODUCTION}

Panulirus argus Virus 1 (PaV1) causes disease in juvenile Caribbean spiny lobsters from the Florida Keys (Shields \& Behringer 2004). It is a large, nonenveloped, icosahedral, presumptive DNA virus with nucleocapsids ranging from 173 to $191 \mathrm{~nm}$ in diameter, and nucleoids approximately $118 \pm 4 \mathrm{~nm}$ in diameter. The virus infects certain hemocytes (hyalinocytes and semi-granulocytes) and spongy connective tissues (Shields \& Behringer 2004). Infected cells have a characteristic appearance with emarginated condensed chromatin, hypertrophied nuclei and faint eosinophilic inclusions. Because PaV1 is widespread in the Florida Keys and is highly pathogenic to juvenile spiny lobsters, Shields \& Behringer (2004) speculated that it might be responsible for recent declines in lobster populations since 1999. However, their study relied on histology and visual diagnosis, which may fail to identify low grade, latent or subclinical infections. Until now, there have been no molecular tools for diagnosis of PaV1 infections.

Diagnosis of viral infections in crustaceans has traditionally relied on clinical signs of disease, histological examination and electron microscopy (Bell \& Lightner 1988, Brock \& Lightner 1990, Johnson \& Cassout 1995). Lately, more sensitive, specific and rapid molecular techniques have been developed as important diagnostic tools for viral pathogens of crustaceans (e.g. Lightner \& Redman 1998). One such method is in situ hybridization (ISH), which detects specific nucleic acid sequences in cells and tissues by hybridization of 
a labeled gene probe to a specific target nucleic acid sequence (Singer et al. 1989). ISH has been subsequently applied to diagnosis of several crustacean viruses, such as Baculovirus penaei (BP) (Bruce et al. 1993, 1994), white spot syndrome virus (WSSV) (Durand et al. 1996, Lo et al. 1997, Nunan \& Lightner 1997, Chang et al. 1998), hepatopancreatic parvovirus (HPV) (Pantoja \& Lightner 2001, Phromjai et al. 2002) and gill-associated virus (GAV) (Spann et al. 2003). ISH has also been applied to the diagnosis of several other pathogens of marine organisms (Stokes \& Burreson 1995, Chang et al. 1996, Lo et al. 1997, Pantoja \& Lightner 2001, Carnegie et al. 2003, Small et al. 2006). It is a useful tool to detect the presence of virions in infected tissues and determine tissue tropism of viral infection in host. Therefore, the objective of this study was to develop a fluorescence in situ hybridization (FISH) assay for the diagnosis of PaV1 infections in lobsters.

\section{MATERIALS AND METHODS}

Sample collection. Juvenile spiny lobsters Panulirus argus were collected from several sites throughout the Florida Keys, USA. Tissue samples of the hepatopancreas, hindgut, foregut, gill, heart, skin, nerve, and in some cases ovary, were dissected and fixed in $10 \%$ neutral buffered formalin for approximately $48 \mathrm{~h}$ and then held in $70 \% \mathrm{EtOH}$ until further process. Fixed tissues were dehydrated, embedded in paraffin and sectioned at $5 \mu \mathrm{m}$ thickness on a rotary microtome. To verify the presence of the virus, sections were stained with hematoxylin and eosin (H\&E) for histology (Humason 1979); infections were further confirmed by transmission electron microscopy (TEM) (Shields \& Behringer 2004). Sections from the same tissue blocks were placed onto positively charged slides (Fisher Scientific) for fluorescence in situ hybridization (see later subsection).

Fluorescent DNA probe synthesis. A 110 bp DNA probe was derived from a $177 \mathrm{bp}$ DNA fragment (GenBank Accession No. DQ465025) that putatively codes for a portion of the DNA polymerase from PaV1 (R. Ratzlaff unpubl. data). The $110 \mathrm{bp}$ DNA probe (PaV1 110) containing fluorescein-12-dUTP (fluorescein isothiocyanate, FITC) was synthesized using a PCR 'fluorescein labeling mix' (Roche Applied Science). A plasmid vector ( $\mathrm{pCR} 4$-TOPO) containing the $177 \mathrm{bp}$ DNA fragment was used as a template for probe synthesis. A specific primer set $(\mathrm{PaV} 1 \mathrm{110 \textrm {F }} / \mathrm{R}$, generated with Invitrogen OligoPerfect ${ }^{\mathrm{TM}}$ Designer) was used to amplify and label a $110 \mathrm{bp}$ fragment from the plasmid DNA containing the 177 bp insert. (See Table 1 for sequence of the 110 bp DNA probe and location of the PaV1 110 F/R primer set.) The polymerase chain reaction (PCR)-labeling reaction was performed according to the manufacturer's instructions (Roche Applied Science). Briefly, each PCR reaction contained the following: PCR buffer at a $1 \times$ concentration, $4 \mathrm{mM} \mathrm{MgCl}_{2}, 200 \mu \mathrm{M}$ PCR fluorescein labeling mix dNTP, $0.5 \mu \mathrm{M}$ of each primer, $1 \mathrm{U}$ Taq DNA polymerase, $100 \mathrm{pg}$ plasmid template, and distilled water $\left(\mathrm{dH}_{2} \mathrm{O}\right)$ to a final volume of $100 \mu$ l. Thermocycling conditions were initial denaturation at $94^{\circ} \mathrm{C}$ for 4 min; 35 cycles of denaturation at $94^{\circ} \mathrm{C}$ for $30 \mathrm{~s}$, annealing at $57.2^{\circ} \mathrm{C}$ for $30 \mathrm{~s}$, and extension at $72^{\circ} \mathrm{C}$ for $90 \mathrm{~s}$; followed by final extension at $72^{\circ} \mathrm{C}$ for $5 \mathrm{~min}$. PCR products were purified using a QIAquick spin purification kit (Qiagen), and were visualized by agarose gel electrophoresis $(2 \%)$ with ethidium bromide staining. The amount of DNA was quantified using a Hoefer DyNA Quant200 fluorometer.

To ensure that the PaV1 $110 \mathrm{~F} / \mathrm{R}$ primer set was amplifying the correct domain of the viral $177 \mathrm{bp}$ insert for synthesis of the $110 \mathrm{bp}$ DNA probe, the PCR was repeated with the fluorescein labeling mix replaced with a standard dNTP mix $(125 \mu \mathrm{M})$. The 110 bp product was visualized by agarose gel electrophoresis, excised from the gel using a sterile scalpel and purified using a QIA-quick gel extraction kit (Qiagen). The amplicon was cloned using a TOPO TA cloning kit for sequencing (Invitrogen) following the manufacturers protocols. Six clones were sequenced bidirectionally and analyzed using an ABI 3130 prism genetic analyzer (Applied Biosystems) as in Dungan \& Reece (2006). Sequences were compared to the original 177 bp fragment using the Clustal-W algorithm in the MacVector DNA sequence analysis package (Accelrys).

DNA probe sensitivity. The sensitivity of the probe was determined by dot-blot hybridization against a 10 -fold serial dilution from $10 \mathrm{ng}$ to $1 \mathrm{pg}$ of plasmid DNA containing the PaV1 $177 \mathrm{bp}$ fragment. Additional controls consisted of $10 \mathrm{ng}$ genomic DNA extracted from the hemolymph of a healthy spiny lobster and 10 ng genomic DNA extracted from the hemolymph of a spiny lobster infected with PaV1 (infection was determined histologically). Genomic DNA was extracted using the DNeasy ${ }^{\circledR}$ tissue kit according to the manufacturer's instructions (animal blood protocol; Qiagen). Briefly, DNA solutions were denatured at $100^{\circ} \mathrm{C}$ for $10 \mathrm{~min}$ and transferred to ice for $5 \mathrm{~min}$. The solution of denatured DNA was loaded onto a positively charged membrane (BrightStar ${ }^{\circledR}$-Plus, Ambion) using a Bio-Rad Microfiltration Apparatus (Bio-Rad Laboratories), and rinsed with $100 \mu \mathrm{l}$ of $0.4 \mathrm{M} \mathrm{NaOH}$. DNA was immobilized by UV crosslinking with a Stratalinker 1800 UV crosslinker (Stratagene). The membrane was placed in a sealed plastic bag containing pre-warmed $\left(42^{\circ} \mathrm{C}\right)$ 
pre-hybridization solution (Sigma-Aldrich) and incubated for 30 min with gentle agitation at room temperature (RT, $\left.25^{\circ} \mathrm{C}\right)$. FITC-labeled probe was denatured as described above, diluted in hybridization buffer (Sigma-Aldrich) to a final concentration of $10 \mathrm{ng} \mathrm{ml}^{-1}$, and incubated with membranes in a sealed plastic bag overnight at $42^{\circ} \mathrm{C}$ with gentle agitation. A series of stringency washes followed: $2 \times \operatorname{SSC}(0.3 \mathrm{M} \mathrm{NaCl}$, $30 \mathrm{mM}$ sodium citrate; $\mathrm{pH} 7.0$ ), $10 \mathrm{~min}, \mathrm{RT}$; $1 \times \mathrm{SSC}$, $10 \mathrm{~min}, \mathrm{RT}$ and $0.1 \times \mathrm{SSC}, 10 \mathrm{~min}, \mathrm{RT}$. The membrane was blocked for $30 \mathrm{~min}$ at RT with blocking buffer (Sigma-Aldrich), then incubated in anti-fluorescein alkaline phosphatase antibody (1:1000 diluted in blocking buffer) (Sigma-Aldrich) for $2 \mathrm{~h}$ with gentle agitation at RT. This was followed by removal of unbound antibody with two 15 min washes with TN buffer (0.1 M Tris, $0.15 \mathrm{M} \mathrm{NaCl}, \mathrm{pH} 7.5)$ and a $5 \mathrm{~min}$ wash with TNM buffer $(0.1 \mathrm{M}$ Tris, $0.1 \mathrm{M} \mathrm{NaCl}, 0.05 \mathrm{M}$ $\mathrm{MgCl}_{2}, \mathrm{pH}$ 9.5). The membrane was then incubated with BCIP/NBT liquid substrate solution (SigmaAldrich) for $2 \mathrm{~h}$ in a sealed plastic bag covered with foil. Color development was stopped with a 5 min TE buffer wash (10 mM Tris, 1 mM EDTA, pH 7.5) and $\mathrm{dH}_{2} \mathrm{O}$ for $5 \mathrm{~min}$. The wet membrane was scanned with a Hewlett Packard Scanjet 3570c scanner for documentation.

Fluorescence in situ hybridization (FISH). The FISH methodology was derived from published ISH protocols (Singer et al. 1989, Stokes \& Burreson 1995, Darby 2000, Beatty et al. 2002). Sections were deparaffinized in xylene (5 $\mathrm{min}, 2 \times)$, rehydrated through a descending ethanol series: $100 \%$ (5 min, $2 \times), 95 \%$ ( $1 \mathrm{~min}, 2 \times), 70 \%$ (1 $\min , 2 \times$ ), and equilibrated in phosphate-buffered saline (PBS; once for $5 \mathrm{~min}$, once for $3 \mathrm{~min}$ ). The sections were then digested with Proteinase K $(100 \mu \mathrm{g}$ $\mathrm{ml}^{-1}$ in PBS) for $15 \mathrm{~min}$ at $37^{\circ} \mathrm{C}$, followed by a $5 \mathrm{~min}$ wash in $0.2 \%$ glycine PBS solution to stop proteolysis, and incubated in $2 \times \mathrm{SSC}$ for $10 \mathrm{~min}$ at room temperature. Slides were incubated in pre-hybridization buffer ( $4 \times \mathrm{SSC}, 50 \%$ formamide, $0.5 \mathrm{mg} \mathrm{ml}^{-1}$ Salmon sperm DNA, and $1 \%$ fetal bovine serum) at $42^{\circ} \mathrm{C}$ for $45 \mathrm{~min}$. After incubation, excess pre-hybridization buffer was carefully drained off, the area with tissue was outlined with a Frame-seal incubation chamber (MJ Research), aliquots of $50 \mu \mathrm{l}$ of hybridization solution (50\% deionized formamide, $4 \times \mathrm{SSC}, 0.5 \% \mathrm{SDS}$, and $25 \mu \mathrm{g} \mathrm{ml}^{-1}$ DNA fluorescein probe) were added, and the slides sealed with a plastic cover slip. The slides were then placed in a thermal cycler for $3 \mathrm{~min}$ at $72^{\circ} \mathrm{C}$ and cooled on ice for $2 \mathrm{~min}$. Slides were incubated in a humid chamber saturated with pre-hybridization buffer overnight at $42^{\circ} \mathrm{C}$. The slides were then washed in $2 \times \mathrm{SSC}$ (5 min), $1 \times \operatorname{SSC}(5 \mathrm{~min})$, PBS (10 min), air dried, mounted with anti-fading mounting medium $(90 \%$ glycerol, $0.1 \mathrm{~m}$ Tris- $\mathrm{HCl}, \mathrm{pH} 8.0$ and $2.3 \%$ DABCO) and covered with glass coverslips. Clear fingernail polish was applied to the edges of the cover slips to prevent evaporation. Slides were examined using an Olympus BX51 microscope equipped with a FITCTexas Red filter (U-MF2, Olympus), and images were captured with a Nikon DXM 1200 digital camera for comparison between matching sections stained with H\&E.

To test the specificity of the probe, tissues with other viral infections were assessed. These included tissues with a herpes-like virus (HLV) from a blue king crab Paralithodes platypus obtained from F. Morado (NOAA) (see Sparks \& Morado 1986); lymphocystis disease virus (LDV) from a striped bass Morone saxatilis, obtained from Wolfgang Vogelbein (VIMS) (see Smail \& Munro 2001 for review); Ostreid Herpesvirus 1 (OsHV-1) from an infected Pacific oyster Crassostrea gigas, obtained from C. Friedman (University Washington) (see Le Deuff \& Renault 1999, Lipart \& Renault 2002) and intranuclear bacilliform virus (IBV) from an infected brown shrimp Crangon crangon from Grant Stentiford (CEFAS, UK) (Stentiford et al. 2004).

TEM. The hepatopancreas from an infected lobster was fixed for transmission electron microscopy (TEM) using $3 \%$ glutaraldehyde (containing $0.2 \mathrm{M}$ sodium cacodylate, $30 \mathrm{mg} \mathrm{ml}^{-1} \mathrm{NaCl}, 20 \mu \mathrm{g} \mathrm{ml}^{-1} \mathrm{CaCl}_{2}, \mathrm{pH} 7.0$ ) (Factor \& Naar 1985). After fixation, tissues were washed 3 times in buffer and postfixed in $1 \%$ osmium tetroxide in buffer. Samples were processed through an ethanol dehydration, en bloc stained with uranyl acetate, dehydrated further with propylene oxide, infiltrated through several changes of propylene oxide in various ratios with Spurr's resin, and finally embedded in Spurr's resin. Sections were cut on a Reichert-Jung ultramicrotome $\mathrm{E}$, processed through a routine lead citrate stain, and observed with a Zeiss CEM-902 TEM.

\section{RESULTS}

\section{DNA probe synthesis and sensitivity}

The primer pair PaV1 110 F/R specifically amplified a single $110 \mathrm{bp}$ fragment (Table 1) when using the plasmid containing the 177 bp DNA fragment as a template in the PCR labeling reaction. The $110 \mathrm{bp}$ DNA probe sequence from 6 clones sequenced was $100 \%$

Table 1. Panulirus argus. Sequence of $110 \mathrm{bp}$ DNA probe from PaV1 and location of PaV1 110 F/R primer set (boldface)

CTCGgTGTAT GgGTTTACGg GGGTGACGAA AAAGGCCATC GGCTTCGAAC CCGTCGCGGC GAGCATCACC GCCGTGGGGC GACAGTCCGT GCTGAAGGCG AAGAAACACT 


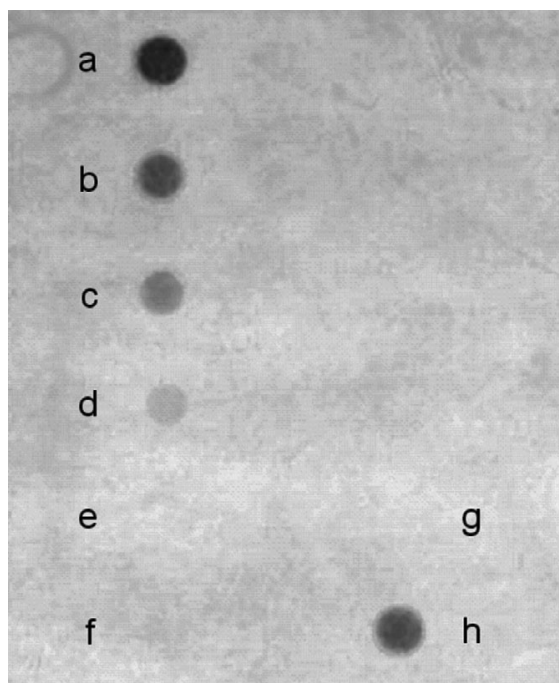

Fig. 1. Panulirus argus. Dot blot hybridization with 110 bp PaV1 probe. Left column of dot blot (a to f) $=10 \mathrm{ng}, 1 \mathrm{ng}, 100 \mathrm{pg}, 10 \mathrm{pg}$, $1 \mathrm{pg}, 0.1 \mathrm{pg}$ of plasmid DNA containing the $177 \mathrm{bp}$ fragment, respectively. Right column of dot blot $(\mathrm{g})=10 \mathrm{ng}$ genomic DNA from hemolymph of healthy lobster; $(\mathrm{h})=10 \mathrm{ng}$ genomic DNA from hemolymph from lobster infected with $\mathrm{PaV} 1$

identical to the corresponding region in the original 177 bp plasmid.

In dot-blot hybridizations (Fig. 1), the probe had a minimum sensitivity of $10 \mathrm{pg}$ of the cloned $177 \mathrm{bp}$ plasmid DNA. Additionally, the probe detected the presence of viral DNA from $10 \mathrm{ng}$ of genomic DNA extracted from the hemolymph of a PaV1 infected spiny lobster. A negative result was obtained when the probe was tested with genomic DNA extracted from the hemolymph of a healthy spiny lobster (Fig. 1g).

\section{Fluorescence in situ hybridization}

The FITC-labeled probe hybridized to PaV1-infected cells in all tissues tested. The probe bound to those infected hemocytes and spongy connective tissue cells in or around the hepatopancreas, hindgut, foregut, gill, heart, skin, nerve and even ovary tissues (Fig. 2A to C). The distribution of FITC-stained structures inside infected cells matched the pathological changes caused by the viral infection when diagnosed by H\&E staining (Fig. 3) and TEM (Fig. 4). Most FITC-stained foci were located around the inner periphery of the hypertrophied nuclear membrane, with a few dispersed throughout the inside of the nucleus.

The probe did not bind to the tissues of healthy spiny lobsters. No FITC-stained particles were present in tissues from healthy spiny lobsters. Only a weak brown/ red background was observed (Fig. 2D). The probe did not hybridize with HLV, OsHV-1, LDV, or IBV.

\section{DISCUSSION}

We have developed a FISH assay for the detection of the recently identified PaV1 virus from the Caribbean spiny lobster Panulirus argus using a sensitive and specific DNA probe. The probe detected $10 \mathrm{pg}$ of plasmid DNA containing a 177 bp DNA fragment from PaV1 in a dot-blot hybridization. It could detect the presence of viral DNA in $10 \mathrm{ng}$ genomic DNA extracted from the hemolymph of a diseased spiny lobster. The probe hybridized to PaV1-infected cells in all tissues tested by FISH. The specific binding of the 110 bp probe for PaV1 was visualized as ring-like green staining of infected cells, whereas only a brown or red background was observed in healthy tissues from uninfected spiny lobsters. This unique distribution pattern of the green staining fits the pattern observed in infected tissue with TEM. Most virions were diffusely distributed within the inner periphery of the hypertrophied nuclei of infected cells, and the probe specifically bound to the complementary sequence of viral DNA in infected cells during in situ hybridization.

Traditional diagnostic tools such as histology or electron microscopy cannot differentiate among certain etiologies. Occasionally, similar pathological signs can be caused by several factors including hypoxia, crowding, a sudden change in environmental factors, or even other pathogens, thus reducing the capacity of certain diagnostic techniques to obtain a specific diagnosis (Lightner 1988). When examined by TEM, PaV1 had properties similar to the Herpesviridae and the Iridoviridae (Shields \& Behringer 2004). It even induces pathological changes similar to those caused by the herpes-like virus (Bi-facies virus, BFV) from the blue crab Callinectes sapidus (Johnson 1976, 1988, Shields \& Behringer 2004). However, the 110 bp probe did not bind with the other viruses: OsHV (Le Deuff \& Renault 1999, Lipart \& Renault 2002), HLV (Sparks \& Morado 1986), LDV (Smail \& Munro 2001) and a virus outside these families, the bacilliform virus (Stentiford et al. 2004). Therefore, the specificity of the probe will facilitate its use in properly diagnosing PaV1 infections in lobsters.

In situ hybridization (ISH) has been applied to diagnose viral diseases in several crustaceans (Lightner \& Redman 1998). A digoxigenin (DIG)-labeled DNA probe used in the diagnosis of Baculovirus penaei detected the baculovirus well before the typical tetrahedral occlusion bodies (TOBs) were observable in routine tissue smears or histological examinations (Bruce et al. 1993, 1994). The probe detected viral infections at $12 \mathrm{~h}$ post-infection, whereas H\&E histology required a minimum of $24 \mathrm{~h}$ for detection. Similarly, Chang et al. (1996) detected WSSV-positive cells 


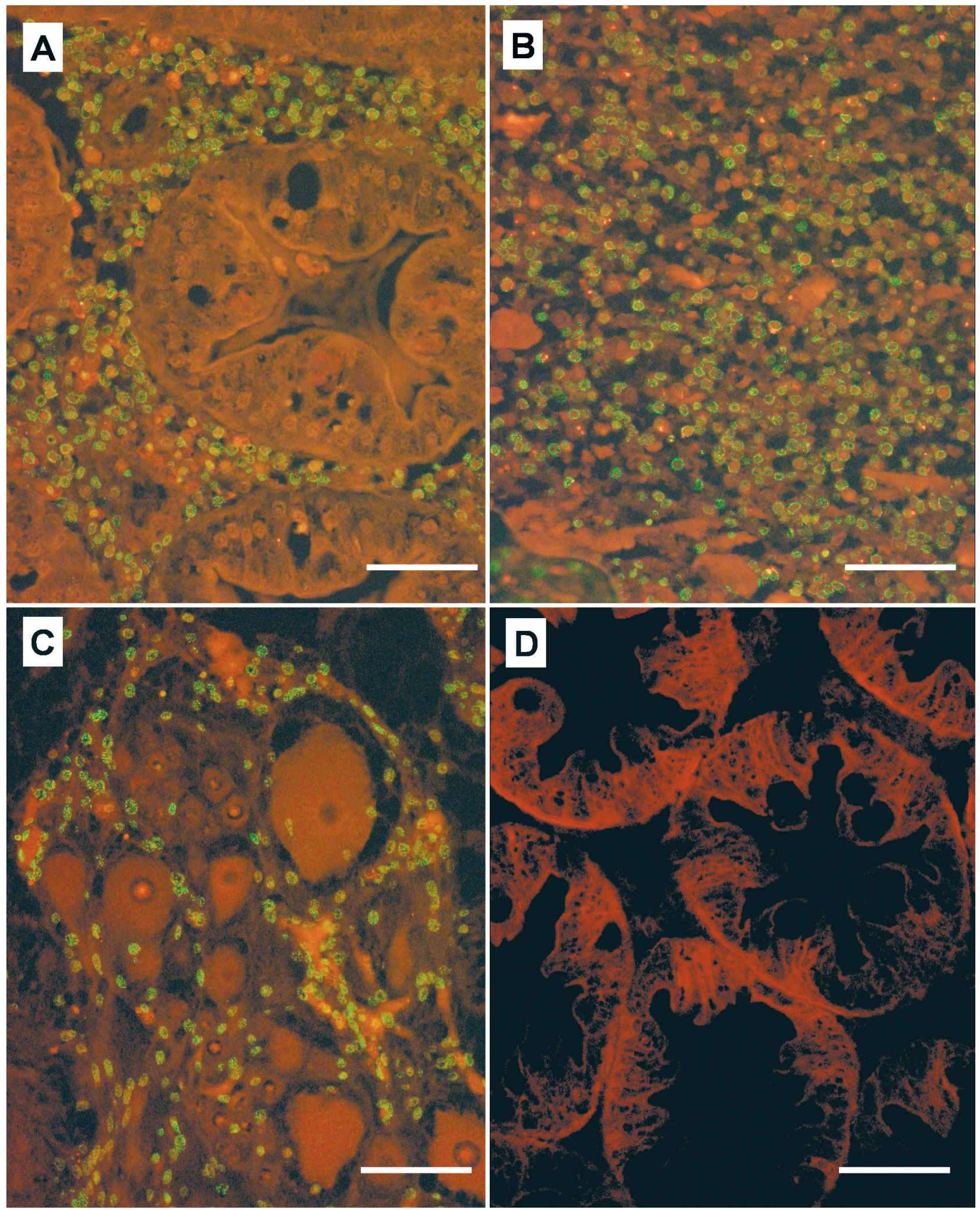

Fig. 2. Panulirus argus. FISH using PaV1 110 bp probe on histological sections of spiny lobster infected with PaV1. (A) Hepatopancreas, (B) spongy connective tissue around foregut, (C) ovary, (D) hepatopancreas from healthy spiny lobster. Green staining indicates specific binding of PaV1 $110 \mathrm{bp}$ probe to viral nucleic acids in infected cells, brown or yellow signal indicates background. Scale bars $=50 \mu \mathrm{m}$ 

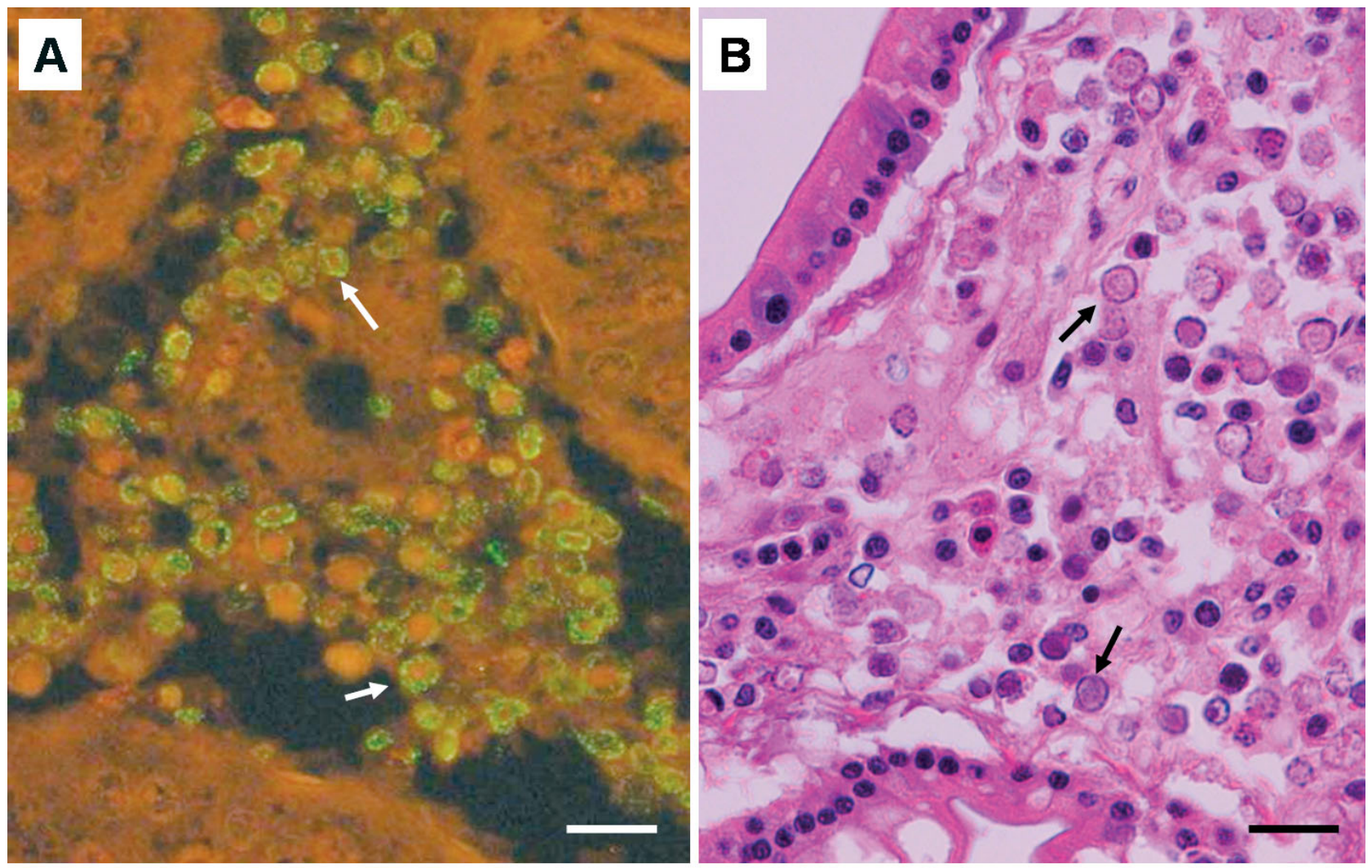

Fig. 3. Panulirus argus. (A) FISH image of hepatopancreas of lobster infected with PaV1; note green staining of virally infected hemocytes by the PaV1 110 bp probe (white arrows). (B) H\&E staining of hepatopancreas of infected lobster; infected cells exhibit hypertrophied nuclei, and faint eosinophilic inclusions; black arrows indicate infected hemocytes. Scale bars $=20 \mu \mathrm{m}$

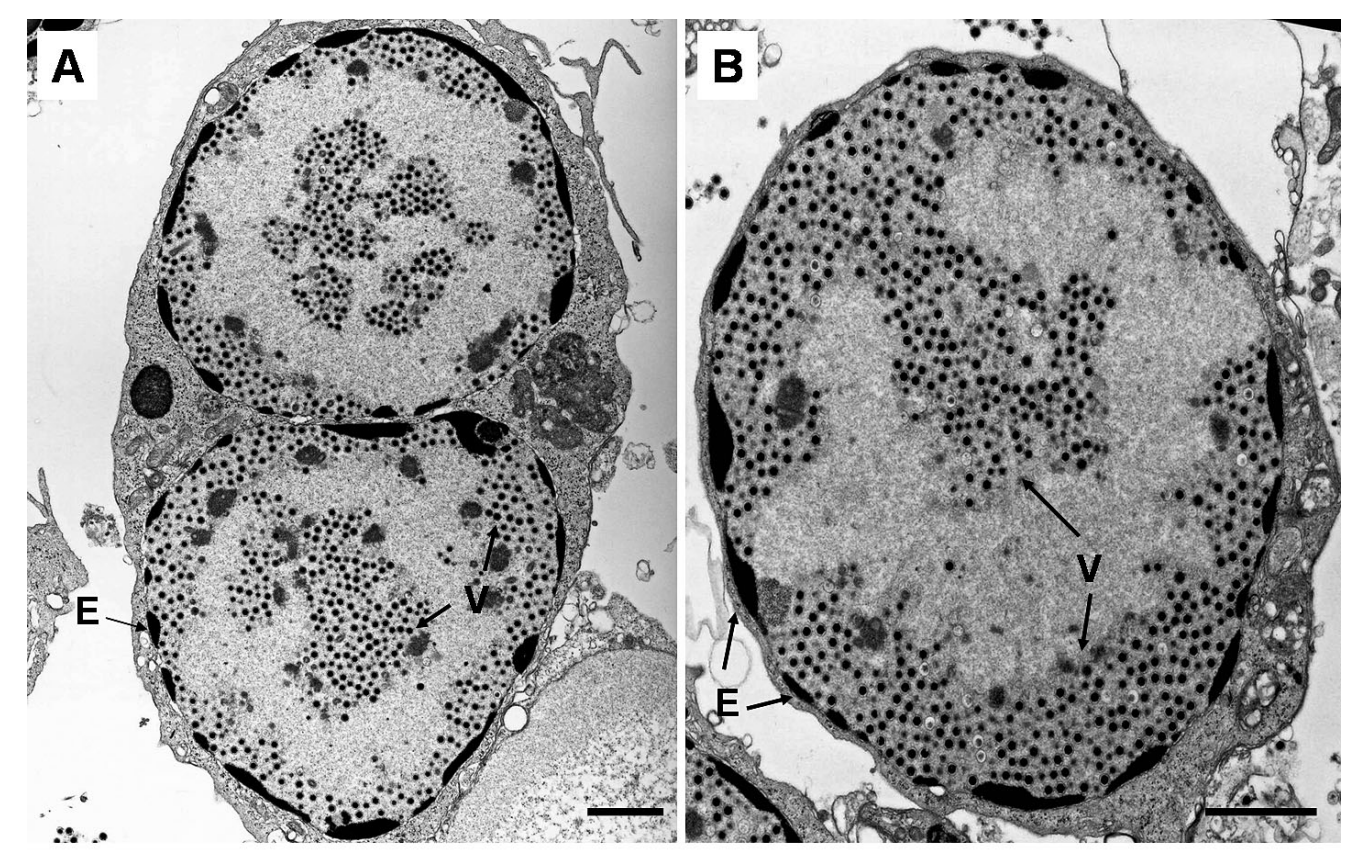

Fig. 4. Panulirus argus. (A,B) TEMs of hepatopancreas from infected lobster, showing virions (V) aggregated at inner periphery of nuclear membrane, with a few dispersed inside the nucleus; note condensed and emarginated chromatin $(\mathrm{E})$. Scale bars $=2 \mu \mathrm{m}$ 
at $16 \mathrm{~h}$ post-infection in the stomach, gill, cuticular epidermis and hepatopancreas of the shrimp Penaeus monodon using a specific DIG-labeled DNA probe. While we have not examined the infection dynamics of $\mathrm{PaV} 1$ over such short time periods, the specific binding of the $110 \mathrm{bp}$ probe, coupled with the excitation sensitivity of FITC to fluorescence, should facilitate examining viral tropism over periods of a few days postinoculation.

Using H\&E and FISH, we found infected cells in the ovaries of an infected lobster. Most of these cells were circulating hemocytes or spongy connective tissue cells; oocytes did not appear to be infected by the virus. Lo et al. (1997) reported that WSSV can infect oocytes in the ovary of the shrimp Penaeus monodon. However, infected oocytes were unable to develop into mature ova; therefore, WSSV was unlikely be transmitted to offspring. In our case, infected juvenile lobsters are not likely to survive to reproduce as they typically die within 30 to $80 \mathrm{~d}$ after infection (Shields \& Behringer 2004). Further, whereas adults can become infected by $\mathrm{PaV} 1$, the prevalence in adults is extremely low (Shields \& Behringer 2004); therefore, transovarial transmission is unlikely to play a major role in the spread of the virus.

Given the sensitivity of the $110 \mathrm{bp}$ PaV1 probe and its apparent specificity, this FISH assay is a powerful tool for detecting the presence of PaV1 virions in host tissues. With this technique we can identify the major tissues involved in infections and the initial sites of viral infection, investigate other hosts as reservoirs for the virus, and monitor disease prevalence in nursery populations of Panulirus argus in the Caribbean Sea.

Acknowledgements. This work was supported by NOAA, Saltonstall-Kennedy Program Grant No. NA17FD2366 and NSF Biological Oceanography Program Grant. No. OCE0136894. We thank Mark Butler, Don Behringer and the staff of FWWC for help with sample collection. Kersten Wheeler and Patrice Mason provided skilled technical support with histology and TEM. Drs. W. K. Vogelbein, D. Gauthier, C. S. Friedman, G. D. Stentiford and F. Morado provided LDV, OsHV-1, IBV, and herpes-like virus samples respectively. This is VIMS Contribution No. 2757.

\section{LITERATURE CITED}

Beatty B, Mai S, Squire J (2002) FISH: a practical approach. Oxford University Press Oxford

Bell TA, Lightner DV (1988) A handbook of normal shrimp histology. Spec Publ World Aquaculture Society, Baton Rouge, LA

Brock JA, Lightner DV (1990) Diseases of Crustacea: diseases caused by microorganisms. In: Kinne O (ed) Diseases of marine animals. Vol III. Biologische Anstalt Helgoland, Hamburg, p 245-325

Bruce LD, Redman RM, Lightner DV, Bonami JR (1993) Application of gene probes to detect a penaeid shrimp baculo- virus in fixed tissue using in situ hybridization. Dis Aquat Org 17:215-221

Bruce LD, Lightner DV, Redman RM (1994) Comparison of traditional and molecular detection methods for Baculovirus penaei infection in larval Penaeus vannamei. J Aquat Anim Health 6:335-359

Carnegie RB, Barber BJ, Distel DL (2003) Detection of the oyster parasite Bonamia ostreae by fluorescent in situ hybridization. Dis Aquat Org 55:247-252

Chang PS, Lo CF, Wang YC, Kou GH (1996) Identification of white spot syndrome associated baculovirus (WSBV) target organs in the shrimp Penaeus monodon by in situ hybridization. Dis Aquat Org 27:131-139

Chang PS, Chen HC, Wang YC (1998) Detection of white spot syndrome associated baculovirus in experimentally infected wild shrimp, crab and lobsters by in situ hybridization. Aquaculture 164:233-242

Darby IA (2000) In situ hybridization protocols, 2nd edn. Humana Press, Totowa, NJ

Dungan CF, Reece KS (2006) In vitro propagation of two Perkinsus spp. parasites from Japanese manila clams Venerupis philippinarum and description of Perkinsus honshuensis n. sp. J Eukaryot Microbiol 53:1-11

Durand S, Lightner DV, Nunan LM, Redman RM, Mari J, Bonami JR (1996) Application of gene probes as diagnostic tools for white spot baculovirus (WSBV) of penaeid shrimp. Dis Aquat Org 27:59-66

Factor JR, Naar M (1985) The digestive system of the lobster, Homarus americanus. I. Connective tissue of the digestive gland. J Morphol 184:311-321

Humason GL (1979) Animal tissue techniques, 4th edn. WH Freeman, San Francisco, CA

Johnson PT (1976) A herpeslike virus from the blue crab, Callinectes sapidus. J Invertebr Pathol 27:419-420

Johnson PT (1988) Development and morphology of an unusual nuclear virus of the blue crab, Callinectes sapidus. Dis Aquat Org 4:67-75

Johnson SK, Cassout D (1995) Electron microscopic examination of negatively stained samples for diagnosis of virus diseases of shrimp. World Aquacult 26:37

Le Deuff RM, Renault T (1999) Purification and partial genome characterization of a herpes-like virus infecting the Japanese oyster, Crassostrea gigas. J Gen Virol 80:1317-1322

Lightner DV (1988) Muscle necrosis of penaeid shrimp. Dev Aquac Fish Sci 17:122-124

Lightner DV, Redman RM (1998) Shrimp diseases and current diagnostic methods. Aquaculture 164:201-220

Lipart C, Renault T (2002) Herpes-like virus detection in infected Crassostrea gigas spat using DIG-labeled probes. J Virol Methods 101:1-10

Lo $\mathrm{CF}_{\text {, Ho } \mathrm{CH}}$, Chen $\mathrm{CH}$, Liu KF and 9 others (1997) Detection and tissue tropism of white spot syndrome baculovirus (WSBV) in captured brooders of Penaeus monodon with a special emphasis on reproductive organs. Dis Aquat Org 30:53-72

Nunan LM, Lightner DV (1997) Development of a nonradioactive gene probe by PCR for detection of white spot syndrome virus (WSSV). J Virol Methods 63:193-201

Pantoja CR, Lightner DV (2001) Detection of hepatopancreatic parvovirus (HPV) of penaeid shrimp by in situ hybridization at the electron microscope level. Dis Aquat Org 44:87-96

Phromjai J, Boonsaeng V, Withyachumnarnkul B, Flegel TW (2002) Detection of hepatopancreatic parvovirus in Thai shrimp Penaeus monodon by in situ hybridization, dot blot hybridization and PCR amplification. Dis Aquat Org 51: $227-232$ 
Shields JD, Behringer DC (2004) A new pathogenic virus in the Caribbean spiny lobster Panulirus argus from the Florida Keys. Dis Aquat Org 59:109-118

Singer RH, Mass S, Lawrence JB, Maplevill RI (1989) In situ hybridization to detect nucleic acid sequences in morphologically intact cells. United States Patent, No. 4888279. Available at: www.singerlab.org/patents/4888278.htm

Smail DA, Munro ALS (2001) The virology of teleosts. In: Roberts RJ (ed) Fish pathology, 3rd edn. WB Saunders, London, p 169-242

Small HJ, Neil DM, Taylor AC, Atkinson RJA, Coombs GH (2006) Molecular detection of Hematodinium spp. in the Norway lobster Nephrops norvegicus and other crustaceans. Dis Aquat Org 69:185-195

Editorial responsibility: Timothy Flegel,

Bangkok, Thailand
Spann KM, McCulloch RJ, Cowley JA, East IJ, Walker PJ (2003) Detection of gill-associated virus (GAV) by in situ hybridization during acute and chronic infections of Penaeus monodon and P. esculentus. Dis Aquat Org 56:1-10

Sparks AK, Morado JF (1986) A herpes-like virus disease in the blue king crab Paralithodes platypus. Dis Aquat Org $1: 115-122$

Stentiford GD, Bateman K, Feist SW (2004) Pathology and ultrastructure of an intranuclear bacilliform virus (IBV) infecting brown shrimp Crangon crangon (Decapoda: Crangonidae). Dis Aquat Org 58:89-97

Stokes NA, Burreson EM (1995) A sensitive and specific DNA probe for the oyster pathogen Haplosporidium nelsoni. J Eukaryot Microbiol 42:350-357

Submitted: April 25, 2006; Accepted: August 31, 2006

Proofs received from author(s): October 19, 2006 